Vol. 11 (1): 49-54 (2021)

\title{
SAFETY AND SECURITY INTERFACE OF RPMS USE TO BROADEN RADIOLOGICAL PROTECTION IN ALBANIA
}

\author{
Dritan Prifti ${ }^{{ }^{*}}$, Kozeta Tushe ${ }^{1}$, Charles Massey ${ }^{2}$, Elida Bylyku$^{1}$, Brunilda Daci $^{1}$ \\ ${ }^{1 *}$ Institute of Applied Nuclear Physics, Street "Thoma Filipeu" Qesarakë, P.O Box 85, Tirana, Albania; \\ ${ }^{2}$ International Atomic Energy Agency, Vienna International Centre, PO Box 100, 1400 Vienna, Austria; \\ *Corresponding Author Dritan Prifti, e-mail: dritan.prifti@unitir.edu.al;
}

Received November 2020; Accepted December 2020; Published January 2021;

DOI: https://doi.org/10.31407/ijees11.107

\begin{abstract}
The basic law for radiation protection in the Republic of Albania is Law no. 8025, dated 11.01.1995 "On protection against ionizing radiation" amended No. 9973, July 28-th 2008, [1] which establishes basic safety standards to protect health of workers and the general public environment against the dangers arising from the ionizing radiation activities. Regulation on Physical Protection of Radioactive Materials in Albania has the objective to establish the basic requirements for physical protection of radioactive sources, and apply to all activities relating to the possession, use, storage and transportation of radioactive sources. Physical protection of radioactive sources aims to protect persons, property, society, and the environment from malicious acts, such as theft or unauthorized removal and sabotage involving radioactive sources. As a result of concern over nuclear and radioactive materials out of regulatory control, Albania has installed a number of Radiation Portal Monitors at various border control points. The main issue in relation to illicit trafficking and smuggling in nuclear materials is to detect any possible illegal transits through Albanian territory and borders and to respond to them properly. The knowledge gained on commodities containing NORM, compliance with transportation and safety requirements, and assessment of alarms will be discussed. The importance of documentation, cooperation between safety and security agencies/organizations, and tools to assess radiation alarms will be also covered.
\end{abstract}

Keywords: ionizing radiation, radioactive sources, radioactive materials, Radiation Portal Monitors 